\title{
Effect of papaya leaves (Carica Papaya) suspension on Japanese quail (coturnix Japonica)
}

\author{
Setara Akter Setu ${ }^{1, *}$, Rakibul Islam ${ }^{2}$, Md. Mahmudul Hasan ${ }^{3}$, Fahima Binthe Aziz ${ }^{4}$, A.S.M. Abu Saeed ${ }^{5}$ \\ ${ }^{1}$ MS student, ${ }^{2}$ Professor, ${ }^{3}$ Assistant Professor, ${ }^{4}$ Associate Professor, ${ }^{5}$ Lecturer,,${ }^{1,2,3,4}$,Dept. of Physiology and Pharmacology, \\ ${ }^{5}$ Dept. of Statistics, HSTU, Dinajpur, Bangladesh
}

*Corresponding Author:

Email: setaraaktersetu2011@gmail.com

\begin{abstract}
Introduction: The experiment was aimed to investigate (i) the comparative efficacy of papaya leaves suspension (PLS) and doxycycline on bacterial load and blood constituents on E. coli inoculated Japanese quail, (ii) the effect of PLS on live body weight, egg production and egg quality (Egg weight, egg shape index, shell plus membrane weight, shell plus membrane thickness, haugh unit, albumen index and yolk index) of Japanese quail.

Materials and Methods: 120 female Japanese quails ten days old were randomly assigned into four groups with three replications and grouped as control group $\left(\mathrm{T}_{0}\right)$, E. coli treated group $\left(\mathrm{T}_{1}\right)$, E. coli plus PLS $(0.25 \%)$ treated group $\left(\mathrm{T}_{2}\right)$ and E. coli plus doxacil-vet powder (1g/2lit) treated group $\left(\mathrm{T}_{3}\right)$ for the aim (i). Ten days old 60 female Japanese quails were randomly assigned into two groups named $\mathrm{T}_{0}$ (control diet) and $\mathrm{T}_{1}(0.25 \% \mathrm{PLS})$ with three replications to fulfill the aim (ii).

Result: (i) microbial load significantly $(\mathrm{P}<0.05)$ decreased in $\mathrm{T}_{2} \& \mathrm{~T}_{3}$ group where significantly $(\mathrm{P}<0.05)$ increased in $\mathrm{T}_{0}$ and $\mathrm{T}_{1}$ group. TEC, Hb, PCV \& ESR in different treatment groups were almost similar and the differences were statistically nonsignificant $(\mathrm{P}>0.05)$ except TLC which was statistically significant $(\mathrm{P}<0.05)$ and the highest TLC was recorded in $\mathrm{T}_{2}$ group.

(ii) The body weight of $\mathrm{T}_{0}$ and $\mathrm{T}_{1}$ at $65^{\text {th }}$ day were 164.95 and $182.32 \mathrm{~g}$ respectively which was statistically significant $(\mathrm{P}<0.05)$. The Hen-day-egg production (HDEP) observed for 15 days were $68.29 \%$ and $73.10 \%$ in $\mathrm{T}_{0}$ and $\mathrm{T}_{1}$ group respectively which statistically significant $(\mathrm{P}<0.05)$. In the treatment groups the external and internal quality of eggs $($ Egg weight, egg shape index, shell plus membrane weight, shell plus membrane thickness, haugh unit, albumen index and yolk index) were almost similar and the differences were statistically non-significant $(\mathrm{P}>0.05)$.

Conclusion: It may concluded that papaya leaf (Carica papaya) suspension have antimicrobial effect and effect on blood constituents, growth performance and egg production of Japanese quail.
\end{abstract}

Keywords: Coturnix japonica, Carica papaya, E. coli, Hematology, Body weight and egg production.

\section{Introduction}

For a long time, the poultry industry in Bangladesh has been dominated largely by broiler and egg layer chicken farming. In the recent past, however, rearing of Japanese quail (Coturnix japonica) for meat and egg production has fast-gained prominence in the country. Japanese quails are prone to almost all diseases that are seen in chickens and other poultry breeds. Quail are susceptible to a variety of bacterial, fungal and parasitic diseases. Among these diseases avian colibacillosis and salmonellosis are considered to be the major bacterial diseases in the poultry industry world-wide. Avian colibacillosis has been noticed to be a major infectious disease in birds of all ages. It is caused by a bacterium called Escherichia coli.

Food safety has become one of the most important public health issues in Bangladesh. Nowadays people become more health conscious. Common pathogenic bacteria that associated with food borne diseases include E. coli. ${ }^{1}$ Quail eggs and meat is gradually gaining popularity in Bangladesh. E. coli infection is considered to be the major bacterial diseases in quail. It can be controlled with antibiotic therapy but a significant increase in drug-resistant strains of $E$. coli has complicated the problem in the poultry industry. Also antibiotics as feed additive can increase abdominal fat in poultry and increase risk of heart disease in consumers. $^{2}$

So, we need to quickly replace of antibiotics with other options. These new options should be inexpensive and available in everywhere as well as healthy for human society. It is thought that medicinal plants are a good alternative for this purpose. Since ancient times, medicinal plants play important role in health management of traditional poultry production. ${ }^{3}$ The extracts of papaya leaves could inhibit the growth of Rhizopus stolonifer. ${ }^{4}$ Antibacterial activities of papaya leaf extracts on pathogenic bacteria was observed in this study. This experiment was conducted to study the antibacterial activity of papaya leaves suspension against $E$. coli infection in quail in comparison with therapeutic dose of doxycycline hydrochloride. Growth promoting activity and effect on egg production of the herb, "Carica papaya", was also studied.

The general objective of this study was to know the effect of papaya leaves suspension in Japanese quail with the following specific objectives:

1. To investigate the antibacterial and hematological effects of papaya leaf on E. coli inoculated Japanese quails

2. To observe the effect of papaya leaf on body weight and egg production performances in Japanese quails. 


\section{Materials and Methods}

1. The experiment was conducted at the experimental shed under the Department of Physiology and Pharmacology and microbial test was performed at microbiology laboratory of the Department of Microbiology, HSTU, Dinajpur, Bangladesh. The experiment was performed for a period of 25 days from $3^{\text {rd }}$ October to $28^{\text {th }}$ October, 2017 to investigate the comparative effect of PLS and doxacil-vet powder suspension on E. coli inoculated Japanese quail. 10 days old 120 female Japanese quail were assigned into four treatments with three replications (each containing 10 quails) per treatment. They were designated as $\mathbf{T}_{\mathbf{0}}=$ Negative control group (Basal diet), $\mathbf{T}_{\mathbf{1}}=$ Positive control group (Basal diet $+E$. coli), $\mathbf{T}_{2}=$ PLS group (Basal diet + E. coli $+0.25 \%$ Papaya leaves suspension) and $\mathbf{T}_{3}=$ Doxycycline group (Basal diet + E. coli + Doxacil-Vet powder @ 1 g per 2 litre water). All groups were supplied $E$. coli orally except $\mathrm{T}_{0}$ group and after 24 hours $\mathrm{T}_{2} \& \mathrm{~T}_{3}$ groups were treated with PLS $(0.25 \%)$ and doxacil-vet powder suspension (1g/2lit) respectively. EMB agar was used for counting CFU (colony forming unit).

Statistical analysis: The collected data were recorded and analyzed by one way ANOVA following Duncan post hoc test using SPSS program version 20 software to find out the difference among the treatments.

2. The experiment was conducted at the experimental shed under the Department of Physiology and Pharmacology and the egg quality determination was performed at Dairy and Poultry Science laboratory under the Department of Dairy and Poultry Science, HSTU, Dinajpur. The experiment was performed for a period of 55 days from $3^{\text {rd }}$ October to $29^{\text {th }}$ November, 2017 to observe the effects of papaya leaves suspension on body weight and egg production of Japanese quail. 10 days old 60 female Japanese quail were assigned into two groups with three replications containing 10 quails in each replication and designated as $\mathbf{T}_{\mathbf{0}}=$ Control group (Basal diet) $\mathbf{T}_{\mathbf{1}}=$ PLS group (Basal diet plus $0.25 \%$ Papaya leaves suspension). Young papaya leaves were collected and washed with fresh water. Before chopping it into small pieces, it was soaked with cotton for removing the adhesive water. Then the leaf was chopped into small pieces and was mashed with the help of pestle and mortar. Leaf juice was collected by squeezing mashed leaf. Then it had been produced $0.25 \%$ of suspension of grinded papaya leaf with distilled water.

\section{Recording of Body Weight}

The quails were weighed just before to the commencement of treatment at the $20^{\text {th }}$ day of age and then every 15 days interval body weight was recorded. Last body weight was recorded at the end of the experimental period $\left(65^{\text {th }}\right.$ day of age) with the help of digital balance.
Hen Day Egg Production: Egg production percent was determined replication wise by the following formula. Hen day egg production (HDEP) (\%)

\section{$=\frac{\text { No.of eggs laid }}{\text { Total no.of days }} \times 100$}

Egg Weight: Weight of each egg was recorded before quality determination by using a digital balance.

Egg Shape Index: Measurements of egg length and width were taken with a caliper to the nearest $0.01 \mathrm{~mm}$. The egg shape index was determined from these measurements according to the following formula.,

Egg shape index $=\frac{\text { Egg width }}{\text { Egg length }} \times 100(\%)$

Albumen Index: The albumen index was determined according to the following formula. ${ }^{7}$

Albumen index =

Average height of thick albumen

Average diameter of thick albumen $\times 100(\%)$

Yolk Index: The yolk index was determined by the following formula. ${ }^{8}$

Yolk index $=\frac{\text { Average height of yolk }}{\text { Average diameter of yolk }} \times 100(\%)$

Haugh Unit: Haugh unit (HU) of egg was calculated according to following formula. $\mathrm{HU}=100 \log (\mathrm{H}+7.57$ $1.7 \mathrm{~W}^{0.17}$ )

Shell plus membrane weight and thickness: Immediately after breaking the eggs, the egg shell was soaked with cotton to remove adhesive albumin and egg shell plus membrane weight was recorded with the help of a digital balance. Egg shell plus membrane thickness $(\mathrm{mm})$ was measured by screw gauze. Three measurements were taken from three different locations of each shell; two reading from the waist region and one reading from each end of egg.

\section{Statistical Analysis}

Data were analyzed by independent-samples t-test. All analyses were performed by SPSS program version 20 . The level of significance was set when the $P$ value is $<0.05$.

\section{Results}

This study showed that, microbial load in feces was significantly differed among the treated groups. Microbial load significantly $(\mathrm{P}<0.05)$ increased in $\mathrm{T}_{0}$ (negative control) and $\mathrm{T}_{1}$ (positive control) group. Microbial load significantly $(\mathrm{P}<0.05)$ decreased in $\mathrm{T}_{2}$ group supplied with $0.25 \%$ papaya leaves suspension and doxacil-vet powder suspension. (Table 1).

The values of TEC, PCV, $\mathrm{Hb}$ and ESR in all treated groups and control group were more or less similar and within the normal range at $22^{\text {nd }}, 27^{\text {th }}$ and $32^{\text {nd }}$ day of age. These values showed a little fluctuation but were not statistically significant $(\mathrm{P}>0.05)$. The values of TLC of $\mathrm{T}_{0}$ (Basal diet) and $\mathrm{T}_{3}$ (E. coli plus doxacil vet powder) group are more or less similar followed by same superscripts in the same column. But in $\mathrm{T}_{1}$ (Basal diet plus E. coli) and $\mathrm{T}_{2}$ (E. coli plus PLS) group, the values are differed followed by different 
superscripts in the same column. The values are also differed between columns among the treated groups. The lowest TLC value $(5851 \pm 58.65)$ was recorded from $\mathrm{T}_{2}$ group at initial stage of experimental period and the highest TLC value was also recorded from $\mathrm{T}_{2}$ group at last stage of experimental period. The TLC value increased in the group $\left(\mathrm{T}_{2}\right)$ fed with $0.25 \%$ papaya leaves suspension. (Table 2).

There were a significant $(\mathrm{P}<0.05)$ increase in body weight in $T_{1}$ (papaya leaf suspension) group than the $T_{0}$ (Basal diet) group. Mean body weights at $20^{\text {th }}$ day of age were 38.85 and 37.79 grams where 164.95 and 182.32 grams mean body weights were found at $65^{\text {th }}$ day of age for $T_{0}$ and $T_{1}$ groups respectively. Birds treated with papaya leaf suspension ( $\mathrm{T}_{1}$ group) had the highest final body weight compared to the birds fed control diet $\left(\mathrm{T}_{0}\right)$. (Table 3 ) The Hen-day-egg production (HDEP) observed for 15 days in two dietary treatments were statistically significant $(\mathrm{P}<0.05)$. Result indicated (Table 4) that the feeding of papaya leaf suspension in the drinking water of laying quail has significant effect on egg production. Quails treated with papaya leaf suspension ( $\mathrm{T}_{1}$ group) showed HDEP (\%) 73.10 where birds of control diet ( $\mathrm{T}_{0}$ group) showed 68.29 HDEP (\%).

Egg weight, egg shape index, shell plus membrane Weight, shell plus membrane thickness, haugh unit, albumen index and yolk index were presented in (Table 5). It was observed that egg weight, egg shape index, shell plus membrane weight, shell plus membrane thickness, haugh unit, albumen index and yolk index of the eggs laid by quails supplied papaya leaf suspension and control diet were almost similar during experimental period and differences were nonsignificant. These results indicated that the experimental birds supplied with papaya leaf suspension had no effect on external and internal qualities of egg. However, egg weight and haugh unit slightly improved in the group $\left(\mathrm{T}_{1}\right)$ supplied with papaya leaf suspension than the group $\left(\mathrm{T}_{0}\right)$ supplied with normal diet. These findings showed dissimilarities with previous study. ${ }^{9}$ They found that diets supplemented with papaya latex had significantly increased shell thickness, egg shape index and haugh unit in eggs of Dokki $_{4}$ hens. These results agree with them in findings of no effect on shell weight, yolk index and albumen index.

Table 1: Effect of papaya leaves suspension and doxycycline on bacterial load in feces of $E$. coli inoculated Japanese quail

\begin{tabular}{|c|c|c|c|c|c|}
\hline $\begin{array}{c}\text { Age } \\
\text { Days })\end{array}$ & $\begin{array}{c}\mathbf{T}_{\mathbf{0}} \\
\mathbf{M e a n} \pm \mathbf{S E M})\end{array}$ & $\begin{array}{c}\mathbf{T}_{\mathbf{1}} \\
(\text { Mean } \pm \text { SEM })\end{array}$ & $\begin{array}{c}\mathbf{T}_{\mathbf{2}} \\
(\text { Mean } \pm \mathbf{S E M})\end{array}$ & $\begin{array}{c}\mathbf{T}_{\mathbf{3}} \\
(\text { Mean } \pm \text { SEM })\end{array}$ & $\begin{array}{c}\text { Level of } \\
\text { significance }\end{array}$ \\
\hline 17 & $10.95 \pm .01^{\mathrm{a}}$ & $11.26 \pm .01^{\mathrm{b}}$ & $11.27 \pm .01^{\mathrm{b}}$ & $11.27 \pm .01^{\mathrm{b}}$ & $*$ \\
\hline 22 & $10.98 \pm .01^{\mathrm{a}}$ & $11.27 \pm .01^{\mathrm{b}}$ & $11.28 \pm .01^{\mathrm{c}}$ & $11.24 \pm .01^{\mathrm{b}}$ & $*$ \\
\hline 27 & $11.01 \pm .01^{\mathrm{a}}$ & $11.33 \pm .01^{\mathrm{c}}$ & $11.25 \pm .01^{\mathrm{b}}$ & $11.05 \pm .01^{\mathrm{a}}$ & $*$ \\
\hline 32 & $11.13 \pm .01^{\mathrm{b}}$ & $11.39 \pm .01^{\mathrm{c}}$ & $11.17 \pm .05^{\mathrm{b}}$ & $10.80 \pm .01^{\mathrm{a}}$ & $*$ \\
\hline
\end{tabular}

Values are expressed as mean \pm standard error of means. $a, b, c$ Means within and between column with different superscripts are statistically different $(\mathrm{P}<0.05) *=$ Significant at $5 \%$ level of significance

Table 2: Effect of treatment with papaya leaves suspension and doxycycline on the different blood parameters (TEC, TLC, PCV, Hb and ESR) of quails inoculated with E. coli

\begin{tabular}{|c|c|c|c|c|c|}
\hline $\begin{array}{l}\text { Age } \\
\text { (Days) }\end{array}$ & $\begin{array}{c}\text { To }_{0} \\
(\text { Mean } \pm \text { SEM })\end{array}$ & $\begin{array}{c}T_{1} \\
(\text { Mean } \pm \text { SEM })\end{array}$ & $\begin{array}{c}\mathbf{T}_{2} \\
(\text { Mean } \pm \\
\text { SEM) }\end{array}$ & $\begin{array}{c}T_{3} \\
(\text { Mean } \pm \\
\text { SEM) }\end{array}$ & $\begin{array}{c}\text { Level of } \\
\text { significance }\end{array}$ \\
\hline \multicolumn{6}{|c|}{ TEC(million/mm³) } \\
\hline 22 & $2.00 \pm 0.15$ & $2.06 \pm 0.28$ & $2.10 \pm 0.10$ & $1.57 \pm 0.28$ & NS \\
\hline 27 & $2.06 \pm 0.28$ & $2.40 \pm 0.15$ & $2.20 \pm 0.25$ & $1.80 \pm 0.02$ & NS \\
\hline 32 & $2.58 \pm 0.03$ & $2.27 \pm 0.03$ & $2.32 \pm 0.02$ & $2.28 \pm 0.28$ & NS \\
\hline \multicolumn{6}{|l|}{ TLC } \\
\hline 22 & $6500 \pm 208.16^{\mathrm{b}}$ & $5799 \pm 284.05^{\mathrm{a}}$ & $5851 \pm 58.65^{\mathrm{a}}$ & $6354 \pm 86.23^{\mathrm{b}}$ & * \\
\hline 27 & $6412.33 \pm 64.3^{\mathrm{b}}$ & $6155 \pm 57.55^{\mathrm{ab}}$ & $6533 \pm 72.64^{\mathrm{b}}$ & $6649 \pm 63.54^{\mathrm{b}}$ & * \\
\hline 32 & $6216.66 \pm 116.67^{\mathrm{b}}$ & $6583.33 \pm 79.57^{\mathrm{b}}$ & $6675 \pm 44.81^{\mathrm{b}}$ & $6260 \pm 100.29^{b}$ & $*$ \\
\hline \multicolumn{6}{|c|}{ PCV (\%) } \\
\hline 22 & $31.21 \pm 0.01$ & $30.85 \pm 0.58$ & $30.76 \pm 0.56$ & $29.87 \pm 0.57$ & NS \\
\hline 27 & $32.14 \pm 0.57$ & $31.29 \pm 0.57$ & $31.87 \pm 0.58$ & $31.66 \pm 0.58$ & NS \\
\hline 32 & $35.71 \pm 0.58$ & $34.63 \pm 0.57$ & $35.67 \pm 0.76$ & $35.65 \pm 0.62$ & NS \\
\hline \multicolumn{6}{|c|}{ Hb (mg/dl) } \\
\hline 22 & $7.69 \pm 0.03$ & $7.72 \pm 0.02$ & $8.10 \pm 0.26$ & $7.59 \pm 0.26$ & NS \\
\hline 27 & $7.79 \pm 0.04$ & $7.72 \pm 0.14$ & $8.04 \pm 0.07$ & $7.87 \pm 0.14$ & NS \\
\hline 32 & $8.09 \pm 0.17$ & $7.79 \pm 0.32$ & $8.30 \pm 0.25$ & $7.88 \pm 0.13$ & NS \\
\hline
\end{tabular}




\begin{tabular}{|l|c|c|c|c|c|}
\hline \multicolumn{6}{|l|}{ ESR (mm/ $\mathbf{1}^{\text {st }}$ hour) } \\
\hline 22 & $10.33 \pm 0.57$ & $10.49 \pm 0.54$ & $11.15 \pm 0.58$ & $11.86 \pm 0.69$ & NS \\
\hline 27 & $10.46 \pm 0.03$ & $10.52 \pm 0.56$ & $10.97 \pm 0.07$ & $11.55 \pm 0.32$ & NS \\
\hline 32 & $11.77 \pm 0.38$ & $10.99 \pm 0.32$ & $10.91 \pm 0.35$ & $12.16 \pm 0.31$ & NS \\
\hline
\end{tabular}

Values are expressed as mean \pm standard error of means. a, b, c Means within and between column with different superscripts are statistically different $(\mathrm{P}<0.05) . *=$ Significant at $5 \%$ level of significance. NS=Not significant

Table 3: Effect of papaya leaf suspension on body weight (g) of Japanese quail.

\begin{tabular}{|l|c|c|c|}
\hline $\begin{array}{c}\text { Age } \\
(\text { Days })\end{array}$ & $\begin{array}{c}\mathbf{T}_{\mathbf{0}} \\
(\text { Mean } \pm \text { SEM) }\end{array}$ & $\begin{array}{c}\mathbf{T}_{\mathbf{1}} \\
(\text { Mean } \pm \text { SEM) }\end{array}$ & $\begin{array}{c}\text { Level of } \\
\text { significance }\end{array}$ \\
\hline 20 & $38.85 \pm 0.76$ & $37.79 \pm 0.20$ & NS \\
\hline 35 & $79.63 \pm 4.89$ & $98.44 \pm 0.94$ & $*$ \\
\hline 50 & $151.55 \pm 0.20$ & $161.13 \pm 2.31$ & $*$ \\
\hline 65 & $164.95 \pm 0.62$ & $182.32 \pm 3.17$ & $*$ \\
\hline
\end{tabular}

Values are expressed as mean \pm standard error of means. Means between columns are statistically different $(\mathrm{P}<0.05), \mathrm{NS}=$ Not significant, $*=$ Significant at $5 \%$ level of significance

Table 4: Effect of papaya leaf suspension on egg production $(\%)$ of laying quails

\begin{tabular}{|l|c|c|c|}
\hline Parameter & $\begin{array}{c}\mathbf{T}_{\mathbf{0}} \\
(\text { Mean } \pm \text { SEM })\end{array}$ & $\begin{array}{c}\mathbf{T}_{\mathbf{1}} \\
(\text { Mean } \pm \text { SEM })\end{array}$ & $\begin{array}{c}\text { Level of } \\
\text { significance }\end{array}$ \\
\hline HDEP $(\%)$ & $68.29 \pm 1.92$ & $73.10 \pm 0.82$ & $*$ \\
\hline
\end{tabular}

Note: Values are expressed as mean \pm standard error of means. Means between column are statistically significant $(\mathrm{P}<0.05) . *=$ Significant at $5 \%$ level of significance

Table 5: Effect of papaya leaf suspension on external and internal quality of egg

\begin{tabular}{|l|c|c|c|c|}
\hline Parameter & $\begin{array}{c}\text { Age } \\
\text { (Days) }\end{array}$ & $\begin{array}{c}\text { T } \\
(\text { Mean } \pm \text { SEM) }\end{array}$ & $\begin{array}{c}\text { T } \\
\text { (Mean } \pm \text { SEM) }\end{array}$ & $\begin{array}{c}\text { Level of } \\
\text { significance }\end{array}$ \\
\hline \multirow{2}{*}{ Egg weight (g) } & 50 & $9.20 \pm 0.01$ & $10.11 \pm 0.32$ & NS \\
\cline { 2 - 5 } & 65 & $9.49 \pm 0.21$ & $10.30 \pm 0.22$ & NS \\
\hline \multirow{2}{*}{ Egg shape index (\%) } & 50 & $77.35 \pm 0.356$ & $77.23 \pm 0.569$ & NS \\
\cline { 2 - 5 } & 65 & $76.98 \pm 0.587$ & $76.78 \pm 0.876$ & NS \\
\hline \multirow{2}{*}{ Shell + Membrane weight (g) } & 50 & $1.67 \pm 0.027$ & $1.66 \pm 0.005$ & NS \\
\cline { 2 - 5 } & 65 & $1.69 \pm 0.04$ & $1.68 \pm 0.03$ & NS \\
\hline \multirow{3}{*}{ Shell + Membrane thickness (mm) } & 50 & $0.22 \pm 0.004$ & $0.23 \pm 0.004$ & NS \\
\cline { 2 - 5 } & 65 & $0.21 \pm 0.004$ & $0.22 \pm 0.003$ & NS \\
\hline \multirow{3}{*}{ Haugh unit } & 50 & $81.44 \pm 0.96$ & $83.80 \pm 0.34$ & NS \\
\cline { 2 - 5 } & 65 & $78.16 \pm 0.48$ & $80.52 \pm 0.87$ & NS \\
\hline Albumen index (\%) & 50 & $9.26 \pm 0.04$ & $9.37 \pm 0.035$ & NS \\
\cline { 2 - 5 } & 65 & $8.86 \pm 0.072$ & $9.00 \pm 0.15$ & NS \\
\hline Yolk index (\%) & 50 & $43.12 \pm 1.43$ & $45.12 \pm 2.39$ & NS \\
\cline { 2 - 5 } & 65 & $42.46 \pm 1.16$ & $44.82 \pm 0.76$ & NS \\
\hline
\end{tabular}

Note: Values are expressed as mean \pm standard error of means. NS=Not significant

\section{Discussion}

In current study, microbial load significantly $(\mathrm{P}<0.05)$ decreased in $\mathrm{T}_{2}$ group supplied with $0.25 \%$ papaya leaves suspension. Previous study showed that papaya leaves have antibacterial activity. ${ }^{4}$

Papaya leaf extracts were tested against Bacillus stearothermophilus, Listeria monocytogenes, Pseudomonas sp. and Escherichia coli by agar diffusion method in that study.

The TLC value increased in the group $\left(\mathrm{T}_{2}\right)$ fed with $0.25 \%$ papaya leaves suspension which agrees with the findings of other studies. ${ }^{9}$ They showed that WBCs were significantly $(\mathrm{P}<0.05)$ increased with addition of papaya latex than those fed control diet experimented on hens and cocks of Dokki ${ }^{4}$ strain.

The increase in WBCs in treated groups might also be concluded leukocytes count. This can be attributed mainly to the antibacterial, antifungal and antioxidant functions of papaya latex. Previous study showed that papaya enzyme increase immune system function. ${ }^{10}$ The white blood corpuscles a good indicator of increasing the immunity efficiency. ${ }^{11}$

There were a significant $(\mathrm{P}<0.05)$ increase in body weight in papaya leaf suspension group than the basal diet group. This weight gain due to papaya leaf containing papain enzyme. Papain is a protease enzyme that hydrolyzes proteins to short peptides which are the 
key factors to increase protein digestibility, fast absorption and helps to increase growth factors. ${ }^{15}$ Previous study also showed significant $(\mathrm{P}<0.05)$ body weight gain for Dokki ${ }^{4}$ laying hens with different levels of papaya latex. ${ }^{9}$ These findings were also confirmed upon examination of papaya latex on rabbits. ${ }^{12-14}$

The experimental birds supplied with papaya leaf suspension had no effect on external and internal qualities of egg. However, egg weight and haugh unit slightly improved in the group supplied with papaya leaf suspension than the group supplied with normal diet. These findings showed dissimilarities with previous study. ${ }^{9}$ They found that diets supplemented with papaya latex had significantly increased shell thickness, egg shape index and haugh unit in eggs of Dokki $_{4}$ hens. These results agree with them in findings of no effect on shell weight, yolk index and albumen index.

\section{Conclusion}

From the current experimental data, it may concluded that papaya leaf (Carica papaya) suspension have antimicrobial effect and effect on blood constituents, growth performance and egg production of Japanese quail. Papaya leaf can also be considered as leukocyte enhancer, efficient growth promoter and remarkable role on egg production in Japanese quail.

\section{References}

1. Clarence, S.Y., Obinna, C.N. and Shalom, N.C. Assessment of microbiological quality of ready to eat food (Meat pie) in Benin City metropolis, Nigeria. African Journal of Microbiological Research. 2009;3(6):390-395.

2. Murwani, R. and Bayuardhi, B. (2007). Broiler serum cholesterol and glutamic oxaloacetic transaminase and their relation to antibiotic in feed and medication programs in four broiler producers in Semarang regioncentral java, Indonesia. International Journal of Poultry Science. 6(4):266-270.

3. Eevuri, T.R. and Putturu, R. (2013). Use of certain herbal preparations in broiler feeds -A review. Veterinary World. 6(3), 172-179.

4. Elisa Friska Romasi, Jessica Karina and Adolf Jan Nexson Parhusip. Antibacterial activity of papaya leaf extracts against pathogenic bacteria. Makara, teknologi. 2011;15(2):173-177.

5. Anderson, K.E., Tharrington, J.B., Curtis, P.A. and Jones, F.T. (2004). Shell characteristics of eggs from historic strains of single comb white leghorn chickens and relationship of egg shape to shell strength. International Journal of Poultry Science. 2004;3:17-19.

6. Reddy, P.M., Reddy, V.R., Reddy, C.V. and Rap, S.P. Egg weight, shape index and hatchability in khaki Campbell duck egg. Indian Journal of Poultry Science. 1979;14:26-31.

7. Heiman, V. and Carven, S.C. (1936). The albumen index as a physical measurement of observed egg quality. Poultry Science. 15: 141-148.

8. Wesley, R.L. and Stadelman, W.J. Measurements of interior egg quality. Poultry Science. 1959;38:474-484.

9. Battaa, El Neney, A.M., Nasra, B., Awadien and Ebeid, T.A. (2015). The productive performance and immunological traits of local chicken strain by using natural enzymes (Plant papain) and remnants of plant papaya. Egyptian Poultry Science Journal. 35 (I): 1-24.

10. Miyamoto, D., Watanabe, J. and Ishihara, K. (2004). Effect of water soluble phospholipids polymers conjugated with papain on the enzymatic stability. Biomaterials. 25:71-76.Wieslaw, P.S.K., Charon, M., Winnicka, A. and Gruszczyñska, J. Relationship between blood lymphocyte phenotype, drb1 (mhc class ii) gene olymorphism and somatic cell count in ewe milk. Journal of Veterinary Research. 2006;50:73-77.

11. Zeedan, K.I.I. and Abdel Latif, M.A. Improvement of immunological and productive performance for buffalo by using some natural additive. 2 . using levels of crude papaya (Carica papaya) latex on productive and reproductive performance in Egyptian buffaloes. Egyptian Journal of Nutrition and Feeds. 2013;16(3):461-477.

12. El Kholy, K.H., Zeedan, K.I.I., El Neney, A.M., Battaa, Omyma, K.I. and Abd El Hakim, A.S. (2008). Study on the optimal crude papaya latex content of growing rabbit diet under summer conditions: Effects on growth performance and immune status. International Journal of Poultry Science. 7:978-983.

13. El Neney, A.M., Battaa, Abd El Hakim, A.S., El Kholy, K.H. and Zeedan, K.I.I. (2013). Effect of crude papaya (Carica papaya) latex supplementation to low protein diets on productive performance, digestion, immune system, activity of certain digestive enzymes and intestinal morphology of growing rabbits. Egyptian Poultry Science Journal. 33:729-750.

14. Wong, M.H., Tang, L.Y. and Kwok, F.S.L. (1996). The use of enzyme digested soybean residue for feeding common carp. Journal of Biology, Hong Kong Bapist University, Kowloon Tong, Hong Kong. 9:418-42. 